------ Raf. J. Sci., Vol. 28, No.3, pp. 1-14, 2019------

\title{
Evaluation of Antibacterial and Antibiofilm Activity of Cinnamon, Clove, Eucalyptus, and Tea Tree Oils Against Oral Streptococci
}

\author{
Shababa A. Bahjat \\ Department of Biology/ College of Science / University of Mosul
}

E-mail: shababababahjat@gmail.com

(Received 3/12/2018; Accepted 22/1/2019)

\begin{abstract}
Biofilm formation is becoming recognized as a key step in many infections. Prevention of this process as well as destruction of pre-formed biofilm are considered key strategies in controlling infectious diseases.

The aim of the present work is to study biofilm formation in oral streptococci isolated from children aged 6-10 years and to test the antimicrobial and antibiofilm activity of four essential oils (Cinnamon, Clove, Eucalyptus, and Tea tree) by using three in vitro methods; Tissue Culture Plate, Tube Method, and Congo red agar for the detection of biofilm formation

Results of this study showed that all oral streptococci exhibited biofilm formation with varying degrees. Also, cinnamon, clove, eucalyptus, followed by tea tree oil not only had a distinctive antibacterial activity against oral Streptococcal isolates, but also possessed anti-biofilm activity. These data provide evidence that plant oils could be potentially used as natural additives, clinically effective, inexpensive and safe plaque control supplements in the prevention of oral diseases.
\end{abstract}

Keywords: Antibiofilm, Antibacterial, Oral Streptococci, Essential oils.

$$
\begin{aligned}
& \text { تقدير الفعالية المضادة للبكتريا والفعالية المضادة لتكوين الغثاء الحيوي لزيوت القرفة، القرنفل، اليوكاليبتوس } \\
& \text { وزيت شجرة الشاي ضد المسبحيات الفموية } \\
& \text { يعد تكوين الغشاء الحيوي من اولويات احداث العديد من الاصابات المرضية. وان ايقاف او تحطيم هذا الغشاء ما قبل تكوينه يعد } \\
& \text { الحل الامتل للسيطرة على الامراض المعدينة. } \\
& \text { الهدف من البحث الحالي هو دراسة تكوين الغشاء الحيوي في المسبحيات التي تعيش في الفم والمعزولة من اطفال تتراوح } \\
& \text { اعمارهم 6-10 سنة فضلا عن اختبار الفعالية التنبيطية وقدرة بعض الزيوت النباتية (القرفة، القرنفل، اليوكاليبتوس وزيت شجرة الثاي) } \\
& \text { في تتبيط انتاج المسبحيات للغشاء الحيوي اذ استخدت ثلاث طرق لهذا الغرض وهي طريقة الاطباق والانابيب ووسط الكونغو } \\
& \text { الاحمر } \\
& \text { اظهرت النتائج قدرة جميع العزلات على انتاج الغشاء الحيوي وبنسب متفاوتة. كما اثتتت الفعالية العالية للزيوت النباتية اعلاه في } \\
& \text { تثبيط نمو المسبحيات فضلا عن ذلك فإن زيوت القرفة و القرنفل واليوكاليبتوس واخيرا زيت شجرة الثاي كان لها القدرة على تقليل نسبة } \\
& \text { تكوين الغشاء الحيوي او تثبيطه مما يتيح استخدامها كمكملات طبيعية للسيطرة على امراض الفم لكونها فعالة، اقتصادية وامنة. } \\
& \text { الكلمات الدالة: الفعالية المضادة لتكوين الغشاء الحيوي، الفعالية المضادة للبكتريا، المسبحيات الفموية، الزيوت النباتية. }
\end{aligned}
$$




\section{INTRODUCTION}

Microorganisms in natural habitats are found as aggregates of cells encased within a selfproduced matrix by which they adhere firmly to each other and/or to living and inert surfaces to form biofilms. The matrix (slime) is composed of extracellular polymeric substance) Flemming et al., 2016); (Colagiorgi et al., 2016). The adherence and survival of biofilms on medical equipments and devices in clinical environments allows pathogens to cause infections. In addition to antimicrobial resistance, bacteria present in a biofilm are also resistant to various physical and chemical stresses, which facilitates biofilms to survive in even the most challenging conditions. Therefore, they are considered as important virulence factors that cause chronic and recurrent infections; they are highly resistant to antibiotics and host immune defenses (Zhang et al., 2018; Reena and anandhalakshmi 2017).

Oral cavity enables adherence of bacteria in the form of biofilms due to the availability of suitable temperature, epithelial debris as nutrients, water, and pH (Roberts and Kreth, 2014). Within hours after birth, initial oral colonization occurs with Staphylococcus epidermidis and Streptococcus species (Nelson-Filho et al., 2013).

Aerobes and obligate anaerobes related mostly to the genera Neisseria, Actinomyces Streptococcus, Veilionella, and some yeasts are the main invading microbes. Following teeth eruption, and as a result of anaerobiosis between gums and teeth anaerobic microorganisms dominate . Finally, the mature oral microbiome contributing to a complex community consists of hundreds of bacterial species (Kaplan et al., 2010).

In the oral cavity, biofilms are composed of multispecies of bacteria, comprising of up to 700 different microbial species, and 100 to 200 of these species can be found in any healthy oral cavity (Kolenbrander et al., 2010). Microbial biofilms may colonize tooth surfaces, tongue, gingiva, and oral mucosa. Oral bacteria is not only responsible for outbreaks of diseases in oral cavity, but could be a cause of systemic diseases like periodontal diseases, osteomyelitis, type 2 diabetes, circulatory system related diseases and bacterial endocarditis (Sharma et al., 2018).

These findings make the control of oral microbes a vital concern because dental plaque biofilm protects pathogenic bacteria from antibiotics. Increasing resistance among pathogens to conventional antibiotics and side effects of current therapie have made plants traditional medicine a potential source to screen for antimicrobial agents (Diego et al., 2018).

Thus, there is an urge for safe and effective antibiofilm approach and eradication. Natural products have been suggested as potentially useful and encouraging antimicrobial and anti-biofilm agents. Essential oils are promising as safe products to ingest with reduced undesired side effects like modified taste, mucosal desquamation and tooth discoloration and finally they present efficient and safe alternatives for dental caries management (Magee, 2007).

The present study aims to detect in vitro antimicrobial efficacy and antibiofilm activity of four essential oils (Cinnamon, clove, eucalyptus and tea tree oils) against oral Streptococci.

\section{Bacterial Isolates:}

\section{MATERIALS AND METHODS}

Saliva samples were collected from 10 children aged 6-10 years. Samples were streaked on selective Mitis Salivarius Agar to obtain isolated colonies of oral streptococci species. A total of 7 oral species and 3 mixed cultures of oral streptococci were included in the present study. Samples were grown under anaerobic conditions (candle jar) at $37^{\circ} \mathrm{C}$ for $24 \mathrm{hrs}$. followed by 24 additional hours at room temperature. Colonies demonstrating dissimilar colonial morphology with gram positive cocci arranged as chains were chosen in the present work. A total of ten monospecies and multispecies cultures were obtained for further investigations. 


\section{Essential oils:}

Four essential oils namely, cinnamon, clove, eucalyptus and tea tree oils were obtained from herbal local store. These oils were chosen following literature survey and their use in traditional medicines (Table 1).

\section{Table 1: Characteristics of essential oils}

\begin{tabular}{|l|l|l|l|l|l|l|}
\hline Product & Scientific name & $\begin{array}{l}\text { Plant } \\
\text { part }\end{array}$ & Main component & $\begin{array}{l}\text { Extraction } \\
\text { method }\end{array}$ & Manufacturer & $\begin{array}{l}\text { Country } \\
\text { of origin }\end{array}$ \\
\hline Tea tree oil & $\begin{array}{l}\text { Melaleuca } \\
\text { alternifolia }\end{array}$ & Leaf & $\begin{array}{l}\text { Alfa terpinene, } \\
\text { y-terpinene and } \\
\text { Terpinen-4-ol }\end{array}$ & $\begin{array}{l}\text { Steam } \\
\text { distillation }\end{array}$ & $\begin{array}{l}\text { Thursday } \\
\text { Plantation }\end{array}$ & Australia \\
\hline Clove oil & $\begin{array}{l}\text { Syzygium } \\
\text { aromaticum }\end{array}$ & Bud & Eugenol & $\begin{array}{l}\text { Steam } \\
\text { distillation }\end{array}$ & $\begin{array}{l}\text { Hemani } \\
\text { International } \\
\text { KEPZ }\end{array}$ & Pakistan \\
\hline Cinnamon oil & $\begin{array}{l}\text { Cinnamomum } \\
\text { zeylanicum }\end{array}$ & Bark & $\begin{array}{l}\text { Cinnameldehyde, } \\
\text { Eugenol }\end{array}$ & $\begin{array}{l}\text { Steam } \\
\text { distillation }\end{array}$ & $\begin{array}{l}\text { International } \\
\text { KEPZ }\end{array}$ & Pakistan \\
\hline Eucalyptus oil & $\begin{array}{l}\text { Eucalyptus } \\
\text { globulus }\end{array}$ & Leaf & $\begin{array}{l}\text { Eucalyptol, alpha- } \\
\text { terpinol }\end{array}$ & $\begin{array}{l}\text { Steam } \\
\text { distillation }\end{array}$ & $\begin{array}{l}\text { Hemani } \\
\text { KEPZ }\end{array}$ \\
\hline
\end{tabular}

\section{Antimicrobial activity of essential oils:}

Antimicrobial screening was determined by employing Kirby-Bauer disc diffusion method (Bauer et al., 1966). Bacterial inoculum were prepared from an overnight culture on Mitis Salivarius Broth. Cultures $(0.1 \mathrm{ml})$ were spread on Mitis Salivarius Agar using sterile cotton swabs, plates were left for 10 minutes at room temperature. Sterile filter paper disks saturated with each essential oil were placed on the plates and incubated for $24 \mathrm{hrs}$. at $37^{\circ} \mathrm{C}$. Inhibition zones were measured in millimeters.

\section{Biofilm Production assays:}

\section{1- Tube Method:}

A qualitative biofilm formation assay was determined for each sample before treatment with essential oil as previously described by (Christensen et al., 1985).

Sterile plastic tubes with $5 \mathrm{ml}$ of BHI with $2 \%$ sucrose were inoculated with a loopful of bacterial samples from overnight culture broths and incubated for $24 \mathrm{hrs}$. at $37^{\circ} \mathrm{C}$. Supernatants were discarded and the tubes were washed with Phosphate buffer saline $(\mathrm{pH} 7)$ and left to dry. Tubes were stained with $0.1 \%$ crystal violet for 20 minutes to visualize biofilm formation. Crystal violet is a dye that stains bacteria's polysaccharide. Excess stain was discarded and tubes were rinsed with distilled water, dried and observed for biofilm formation. Positive biofilm formation was demonstrated by a visible film lining the wall and bottom of the tube. Based on biofilm production, the positive results were recorded as strong $(+++)$, moderate $(++)$ and weak $(+)$.

\section{2- Congo Red Method:}

This method was recommended by (Freeman et al., 1989). It requires a specially prepared solid medium BHI broth supplemented with 5\% sucrose and congo red. The medium is made of brain heart infusion broth $(37 \mathrm{gm} / \mathrm{l})$, sucrose $(5 \mathrm{gm} / \mathrm{l})$, agar $(10 \mathrm{gm} / \mathrm{l})$ and congo red dye $(0.8 \mathrm{gm} / \mathrm{l})$. A concentrated aqueous solution of congo red stain was prepared and autoclaved at $121^{\circ} \mathrm{C}$ for 15 minutes. Then it was added to the autoclaved brain heart infusion agar with sucrose at $55^{\circ} \mathrm{C}$. Congo red directly reacts with certain polysaccharides in the biofilm .The congo red agar plate was streaked with the bacterial isolates from an overnight culture plate and aerobically incubated at $37^{\circ} \mathrm{C}$ for $24-48 \mathrm{hrs}$. Biofilm production is 
indicated by black colonies with a dried crystalline consistency, intermediate biofilm is shown by dark colonies without crystalline colonies, and pink colonies indicate a weak biofilm production.

Positive biofilm production by any one of the previous methods was considered as positive for biofilm formation.

\section{Biofilm inhibition assays:}

1- Tube Method (TM):

Evaluation of the ability of different concentrations of essential oils to inhibit biofilm production by monospecies and multispecies streptococci samples was performed on plastic disposable tubes. A qualitative method for the detection of biofilm formation was performed as described by (Christensen et al., 1985). Briefly, different concentrations (1,2, and 3\%) of essential oils were prepared in BHI broth. Two $\mathrm{ml}$ of each concentration were inoculated with $0.1 \mathrm{ml}$ bacterial sample and incubated for 18-24 hrs. Biofilms were stained with crystal violet as mentioned above. A positive biofilm producer was indicated by a visible film along the inner wall and bottom of the tube. Results were compared and graded visually

\section{2- Microtiter Plate assay (MTP):}

MTP method was also used to evaluate the efficacy of essential oils in inhibiting biofilm formation using 96 well-flat bottom polystyrene titer plates according to (Christensen et al., 1985). Individual wells were filled with $180 \mu \mathrm{L} \mathrm{BHI}+2 \%$ sucrose broth followed by inoculation with $10 \mu \mathrm{L}$ of overnight culture. To this $10 \mu \mathrm{L}$ of each essential oil was added from a stock solution of $0.5 \%, 1 \%$, $1.5 \%$ concentrations respectively along with control (media only) and incubated at $37{ }^{\circ} \mathrm{C}$ for $24 \mathrm{~h}$. After incubation, contents of wells were decanted and then washed with $0.2 \mathrm{ml}$ of phosphate buffer saline (PBS) $\mathrm{pH} 7.2$ to remove free floating bacteria. The adhered sessile bacteria were stained with crystal violet $(0.1 \%, \mathrm{w} / \mathrm{v})$ for 20 minutes. Excessive stain was decanted, washed with sterile saline and kept for drying. Dried wells were washed with $95 \%$ ethanol and Optical Densities (OD) was measured using micro ELISA auto reader at OD $630 \mathrm{~nm}$. Mean OD value $<0.120,0.120-0.240$ and $>0.240$ were classified as non/weak, moderate and strong biofilm adherence respectively (Mathur et al., 2006).

\section{Isolation of Bacterial Isolates:}

\section{RESULTS AND DISCUSSION}

Saliva samples collected from children were streaked on Mitis Salivarius Agar; a selective medium used to isolate oral streptococci and differential because each species of streptococcus has a distinguished colony morphology. The medium contains selective agents (Crystal violet, trypan blue, and potassium tellurite) that inhibit gram-negative bacilli and gram-positive bacteria except streptococci and enterococci. Potassium tellurite is reduced by Enterococcus spp. to form black colonies. S. salivarius metabolizes sucrose and develops colonies with a "gum-drop" appearance. $S$. mitis and enterococci do not metabolize sucrose and, form smaller colonies on this medium. Trypan Blue is absorbed by streptococci colonies producing a blue color. Colony morphology of Streptococcus species obtained on Mitis salivarius agar, as seen under a light microscope, and gram stain are shown in Figs. (1), (2) and (3) respectively: 

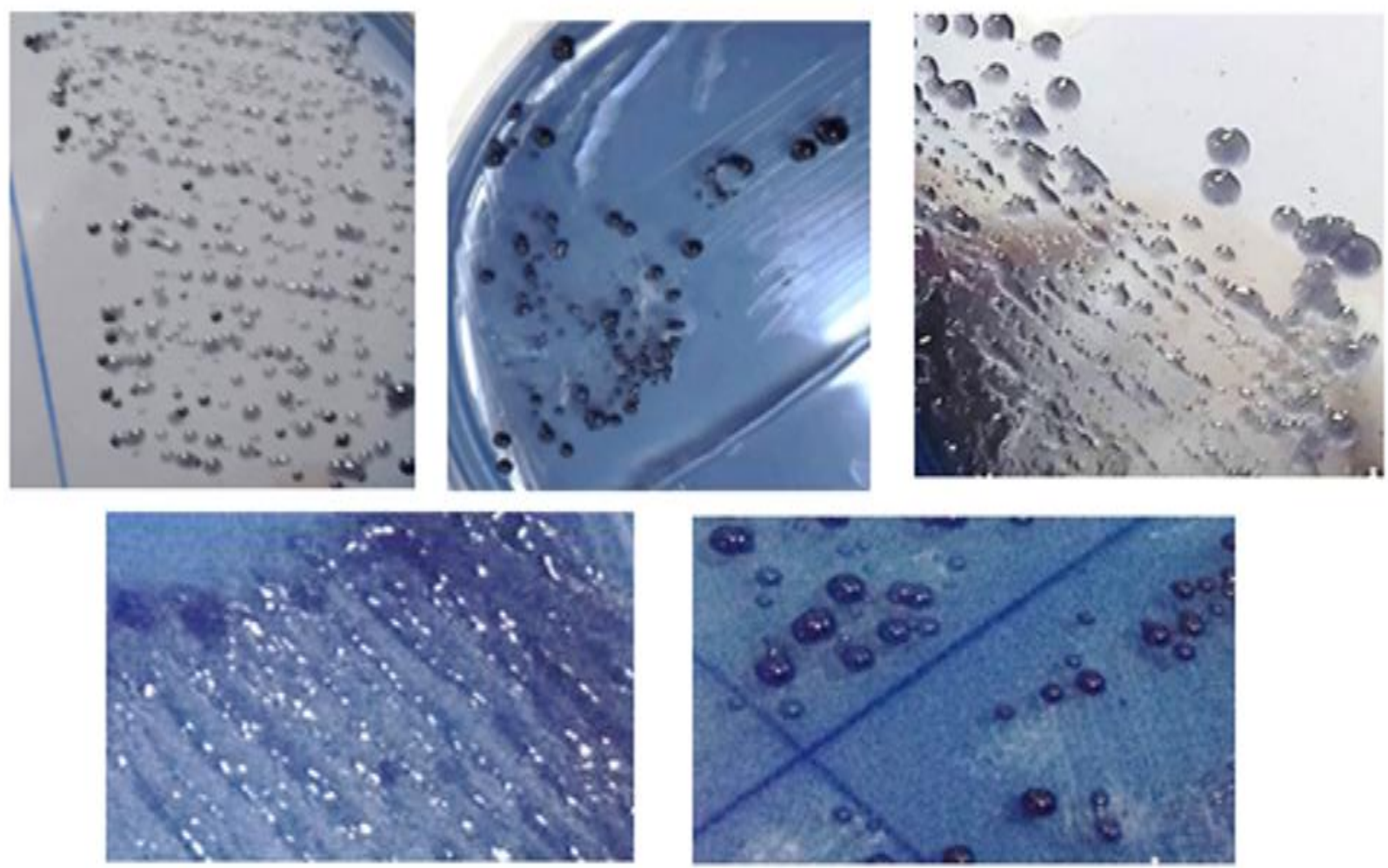

Fig. 1: Colony morphology of oral Streptococci after 48 hrs. showing monospecies and multispecies cultures on Mitis Salivarius Agar.

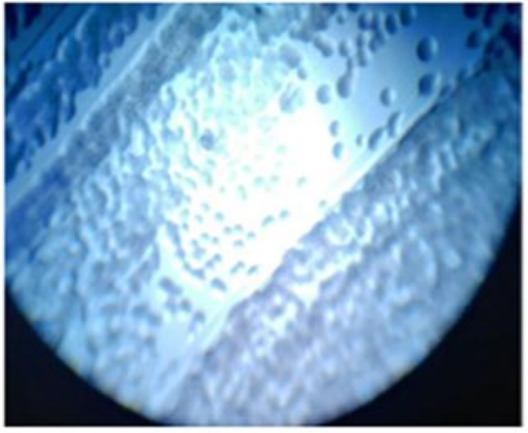

A

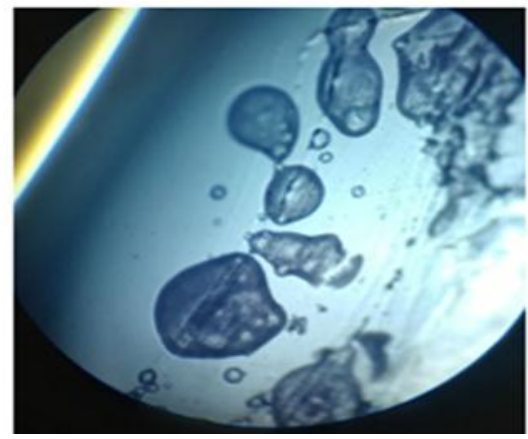

D

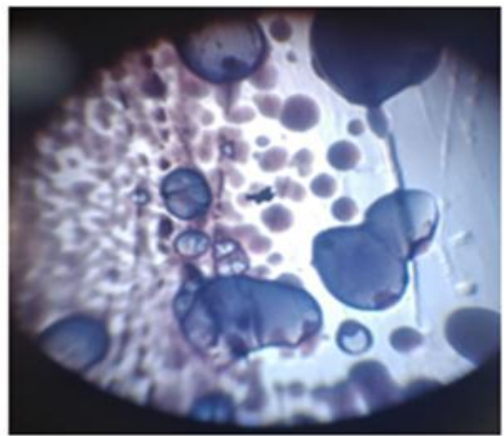

B

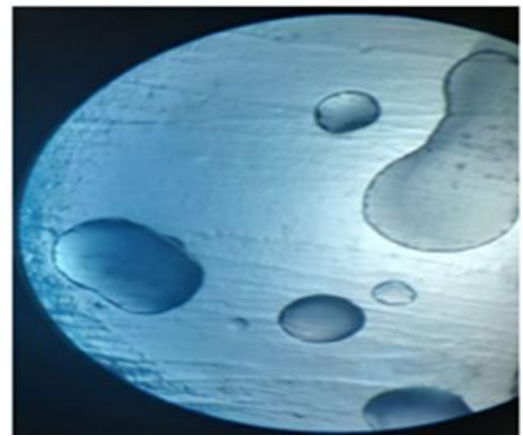

$\mathbf{E}$

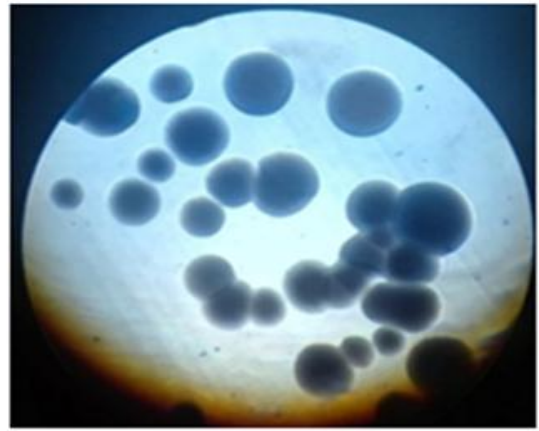

C

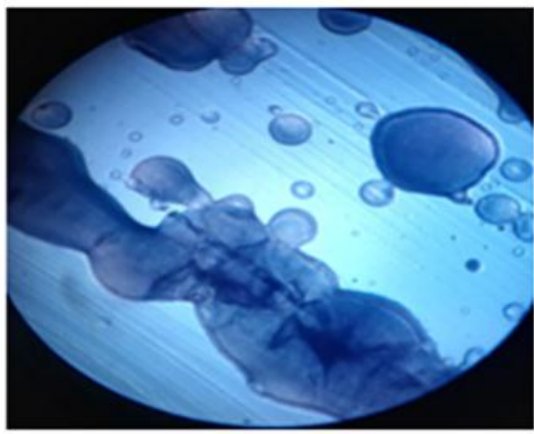

F

Fig. 2: Colonial morphology of oral Streptococci on Mitis Salivarius Agar as seen under the microscope ( 4x). A, B, D, F monospecies. C,E multispecies cultures. 

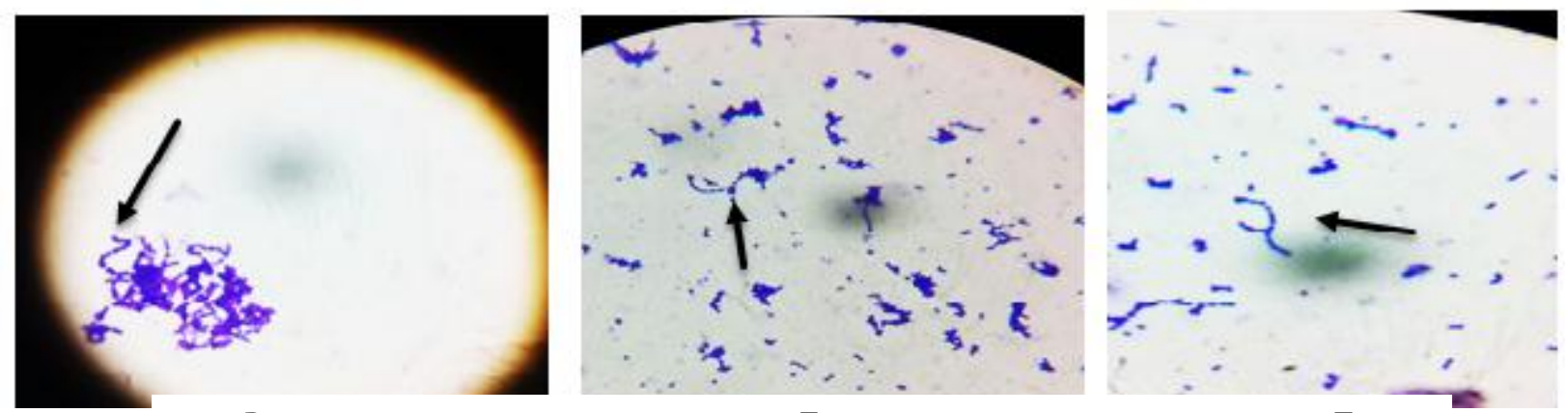

\section{Antimicrobial screening:}

Fig. 3: Gram stain of oral streptococci ( 100X )

Disc diffusion method is considered the most common procedure for testing antimicrobial susceptibility. Antibacterial screening of the four oils was studied revealed that all four essential oils had a varying degree of inhibiting both mono and multispecies streptococcal biofilm producing bacteria Fig. (4).
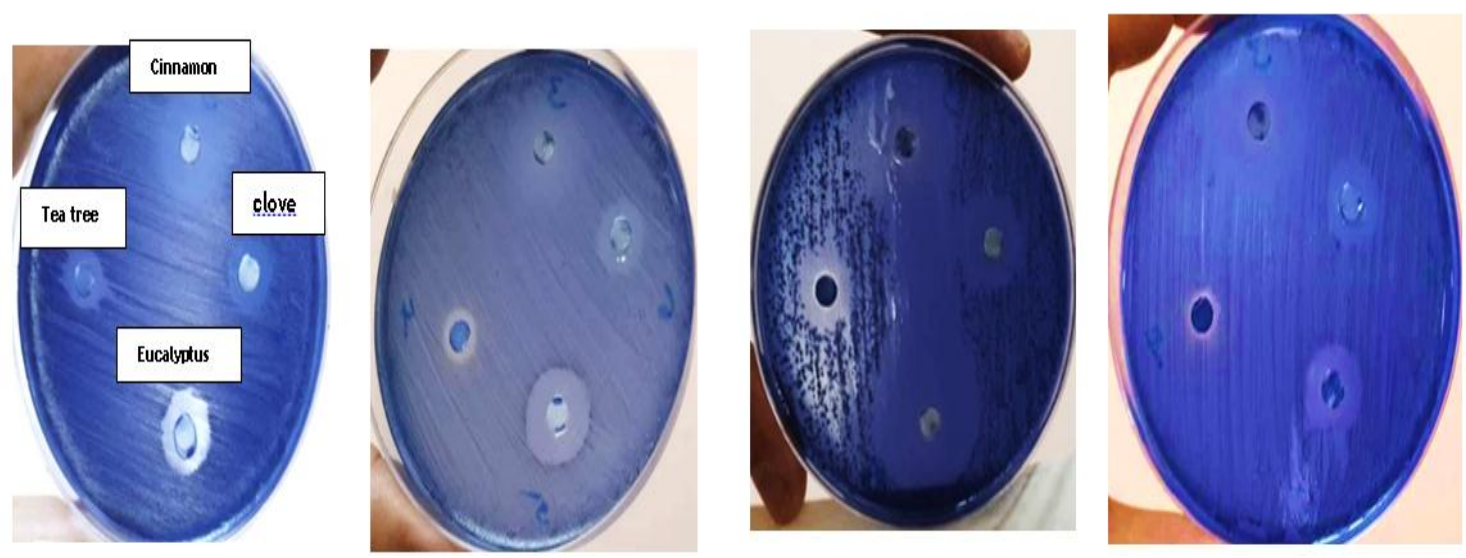

Fig. 4: Antibacterial activity of cinnamon, tea tree, eucalyptus and clove oil on oral streptococci

According to the standard zones of inhibition claimed by (Guevara, 2005) shown in (Table 2) cinnamon oil was partially active against 3 isolates but very active against six samples. All mono and multispecies were susceptible to it. Inhibition zones ranged from 11-30 $\mathrm{mm}$. This relates to many previous studies evaluating antibacterial efficacy of cinnamon (Wang et al., 2018); (Swamy et al., 2015). In addition to a study by (Rohraff and Morgan, 2016) which suggested that cinnamon bark oil may contain a potential novel antibiotic.

Table 2: Standard inhibition zones claimed by (Guevara, 2005)

\begin{tabular}{ll}
\hline \hline Zones of inhibition & Inferences \\
\hline$<10 \mathrm{~mm}$ & Maybe expressed as inactive \\
$10-13 \mathrm{~mm}$ & Partially active \\
$14-19 \mathrm{~mm}$ & Active \\
$>19 \mathrm{~mm}$ & Very active \\
\hline
\end{tabular}


Antibacterial activity of four essential oils namely; cinnamon, clove, eucalyptus, and tea tree oils against various mono and multispecies oral Streptococci is revealed in Fig. (5).

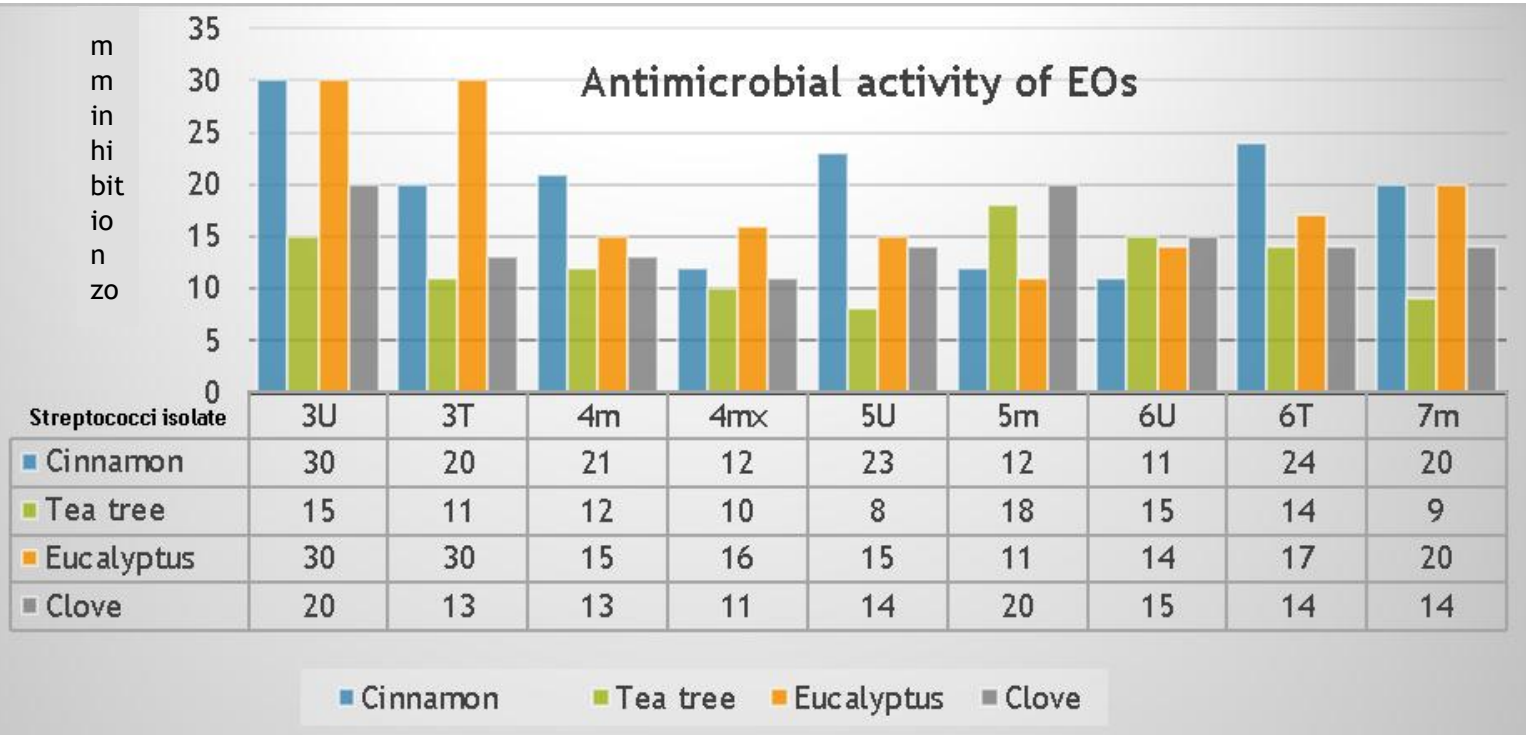

Fig. 5: Antibacterial activity of essential oils used against mono and multispecies of oral
streptococci

Cinnamon is locally available and has been used safely in traditional medicine for decades .The active ingredient of cinnamon oil is eugenol, a widely used antibacterial agent in dentistry and has been proven to reduce halitosis (Katyayani et al., 2017). Eugenol is a phenolic compound from clove (Eugenia caryophillis) and cinnamon (Cinnamomum zeylanicum) leaves. A review by (Freires et al., 2015) has shown that eugenol has an antimicrobial activity against streptococci, specifically $S$. mutans, and should be advised as an anti-cariogenic agent. Another major constituent in the C. zeylanicum bark oil is cinnamal-dehyde followed by $\alpha$-pinene $(1.4 \%)$ and cis-beta ocimene $(1.3 \%)$. The rest of the constituents are present in less than $1 \%$. The cinnamaldehyde is chief component of cinnamon bark oil (Wang et al., 2018).

The present study also indicated that eucalyptus oil was highly active against 8 out of ten isolates, and partially active against a multispecies sample. This coincides with a study by (Mota et al., 2015) who demonstrated that Eucalyptus globulus essential oil has a more potential antimicrobial activity than chlorhexidine against gram-positive and gram-negative bacteria.

The essential oil components of the genus Eucalyptus (Myrtaceae) have been well defined. Eucalyptus species produce large amounts of various volatile compounds especially isoprenoids, found in glands located in the leaf parenchyma and bark (Bruneton 1999). The value of Eucalyptus oil for medical purposes is due to the content of the specific oil ingredient: 1,8-cineole (cineole or eucalyptol) (Gondim et al., 2018) .

Tea tree oil was inactive against two samples one mixed and a multispecies sample .However it was active on 8 out of ten samples with an inhibition zone of 10-15 mm.Tea tree oil is derived from the Australian native plant, Melaleuca alternifolia. Tea tree oil is composed of terpene hydrocarbons, and their alcohols. Antimicrobial activity of tea tree oil is mostly due to 1,8-cineole, $\alpha$-terpineol and terpinen-4-ol. These components cause leakage of $260 \mathrm{~nm}$-light absorbing material. Consequently, cells become vulnerable to sodium chloride. In addition to that, tea tree oil interacts with intracellular constituents, which leads to the disruption of crucial cell functions and cell death ( Thosar et al., 2013). It has been shown to inhibit different types of bacteria. However, in the 
present study results showed that 3 samples out of ten resisted it compared to the rest of the essential oils which were all active against streptococci. A study by (Singh et al., 2016) also found that only $20.5 \%$ strains (45 out of the 550) strains genera were sensitive to tea tree oil, even less than the least potent antibiotic (novobiocin). The difference might be due to that most of the strains involved clinical isolates while earlier studies are mostly reported on reference strains. The tea tree essential oil has antibacterial activity against microorganisms evaluated but in high concentrations (Leite et al., 2017).

However, the current results were not in accordance with the results of (Hammer et al., 2003) who conducted a study to determine the antibacterial action of tea tree oil. A total of 162 bacterial isolates from streptococcus and other genera. All isolates were inhibited and killed by concentrations of tea tree oil $2 \%$, most were inhibited or killed at concentrations below this.

The present study also showed that Clove oil was effective against all samples with inhibition zones ranging from 11-20 mm in agreement with many studies which considered oil of clove a substance with a strong antimicrobial activity (Rodríguez et al., 2014). In their study, eugenol was characterized as as an active antimicrobial agent. Its activity against Streptococcus was observed, agreeing with several studies which reported its growth inhibitory activity in oral pathogens (Wazir bin Jumali et al., 2013).

In general, activity of essential oils is determined by their constituents, active ingredient, functional groups, and their synergistic interactions. The antimicrobial mechanism of action varies with the type of essential oil or bacterial strain used. It is well known that gram-positive bacteria are more susceptible to essential oils compared to gram-negative bacteria, (Huang et al., 2014). This is due to the fact that Gram-negative bacteria have a complex rigid lipopolysaccharide (LPS) outer membrane which controls the diffusion of hydrophobic compounds through it, on the other hand this membrane is not present in gram-positive bacteria, which has a thick peptidoglycan wall that cannot resist small antimicrobial molecules attempting to pass through the cell membrane. Moreover, gram-positive bacteria may facilitate the penetration of hydrophobic compounds of essential oils.

A study by (Lopez et al., 2015) presumed that essential oil molecules bind strongly with surface me mbrane proteins of the cells which are vital for growth and survival. Afterwards, they can form a monolayer around the cell that changes the hydrophobicity and electrostatic potential, resulting in release of internal cellular components.

Also, essential oils are capable of penetrating mucous membranes. Therefore, their supragingival application has a promising beneficial effect (Sreevidhya and Geetha, 2014).

Evidence on the chemical properties of phytochemicals indicate that the hydrophobicity seems to result in higher antimicrobial effect (Ribeiro et al., 2018).

\section{Biofilm Production assays: \\ 1- Tube Method:}

All oral Streptoccocus isolates were assayed for biofilm production by the qualitative Tube Method. Fig. (6) reveals the various degrees of biofilm forming ability of the isolates included in the current study. 


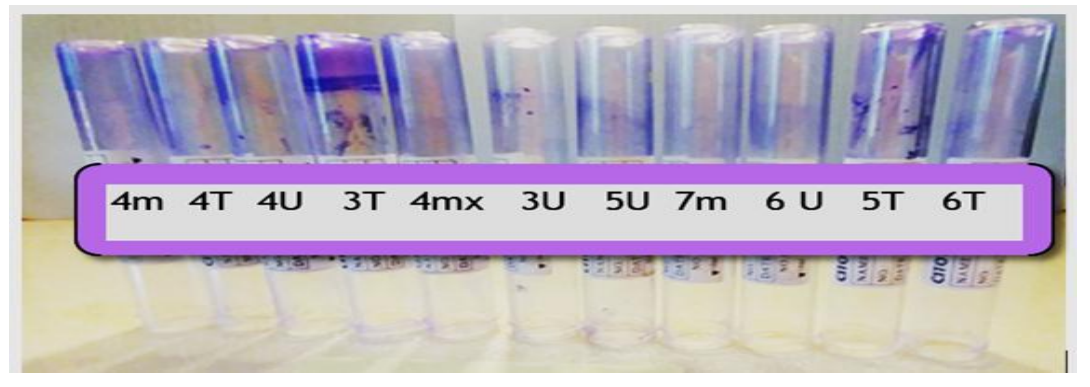

\section{Fig. 6: Biofilm detection of oral Streptococcal isolates $(4 m-6 t)$ using Tube method}

Biofilms can be formed by single, or polymicrobial species of microorganisms. Polymicrobial growth brings with it interspecies relationship like communication, metabolic cooperation, and quorum sensing. The interactions can be of synergistic (cooperative), antagonistic (competitive) or neutral depending on the genetic background of the species involved (Jitka et al., 2017).

Synergistic actions may promote biofilm formation by co-aggregation, or metabolic cooperation (one species benefits from metabolites produced by other species), also it can lead to an increased resistance to host immune responses and antibiotics compared to mono-species biofilms.

Antagonistic interactions may be by competition over nutrients and growth inhibition. Therefore, coaggregation of many species of bacteria in biofilms can lead to an increase or decrease in biofilm production.

\section{2- Congo Red Agar Method:}

Among ten isolates, only one $(7 \mathrm{~m})$ was shown to be a non-biofilm producer. Results are clearly shown in Fig. (7).
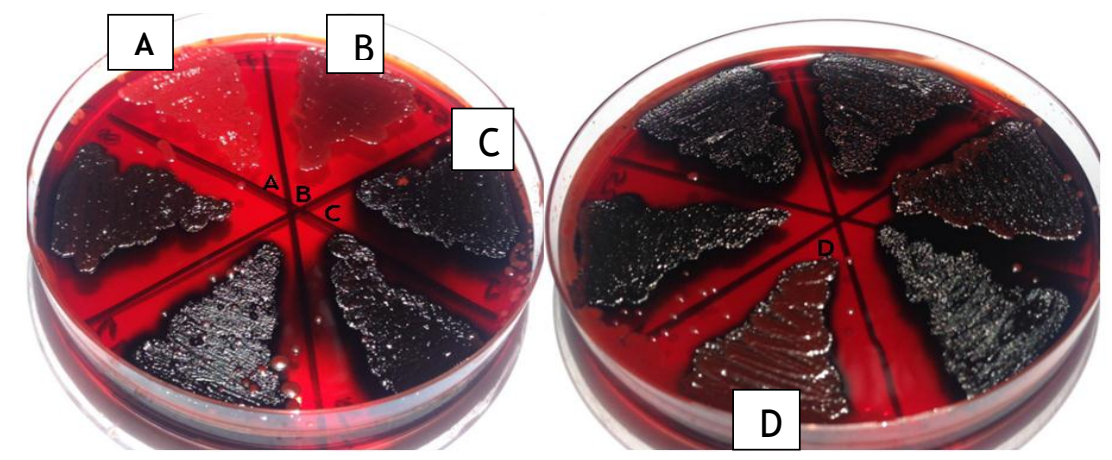

Fig. 7: Congo red method for biofilm detection. A: Biofilm non producer B: Weak producer, C: Strong Producer and D: Intermediate biofilm producer.

\section{Biofilm inhibition assay:}

\section{1- Tube Method:}

Clove oil has shown to be effective in one concentration or another to inhibit biofilm in 7 out of ten isolates. There was a variation in the response to different concentrations among the tested isolates (mono and multi- species). Fig.(8) clearly demonstrates the diminished biofilm production by the streptococci isolate 5t (monospecies sample) at the concentration 1 and $2 \%$. Streptococci $4 \mathrm{mx}$ and $4 \mathrm{~m}$ (multispecies) were also affected by $1 \%$ concentration although biofilm production was stimulated at higher concentrations. 


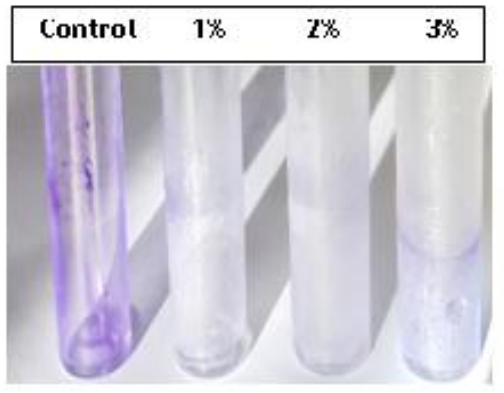

$5 \mathrm{t}$

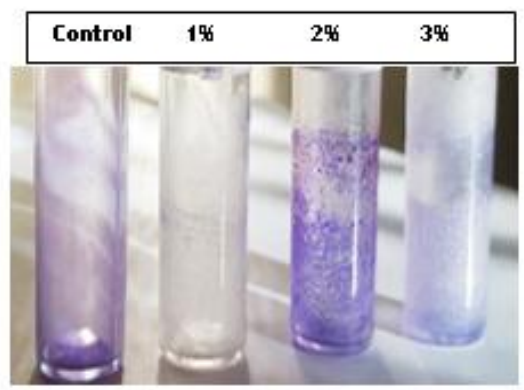

$4 m x$

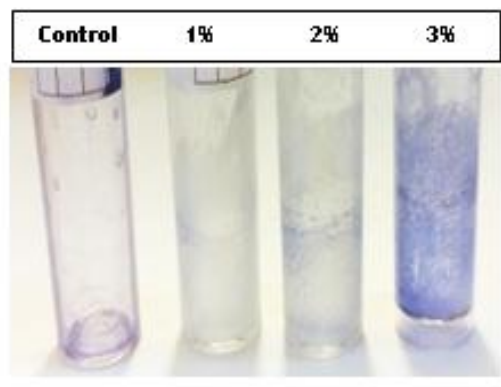

$4 m$

Fig. 8: Antibiofilm activity of clove oil on oral Streptococci.

Cinnamon: Most isolates used in the present study showed a decrease in biofilm preogression rather than inhibition. In addition to a few where there was a biofilm stimulation.

Tea tree oil: This method confirmed the ability of tea tree oil as an antibiofilm agent that inhibited all oral streptococci at 1 and $3 \%$ concentrations as shown in Fig. ( 9 ).

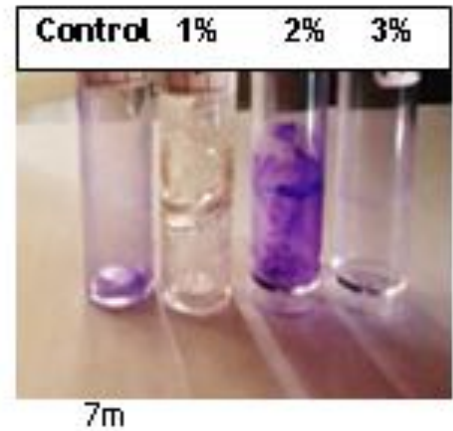

Fig. 9: Antibiofilm activity of tea tree oil on oral Streptococci.

Eucalyptus oil: Results clearly showed a strong antibiofilm activity against 7 out of ten. samples. Most strains demonstrated a decrease of biofilm reduction as the concentration increased Fig. (10).

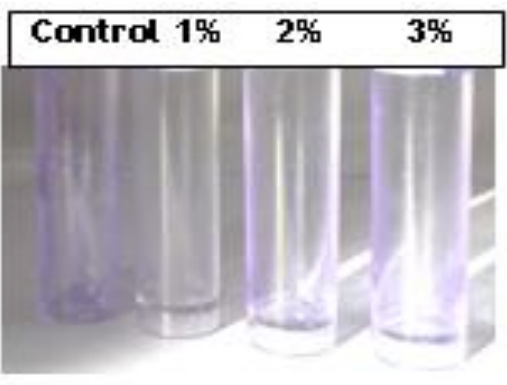

$5 T$

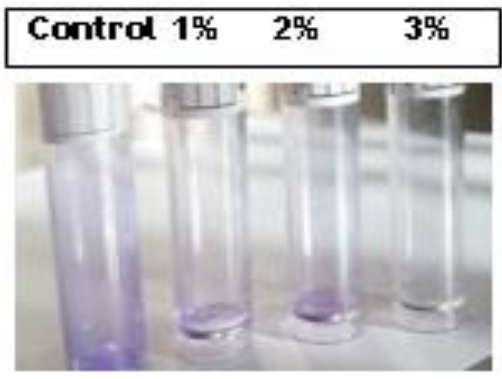

$4 m x$

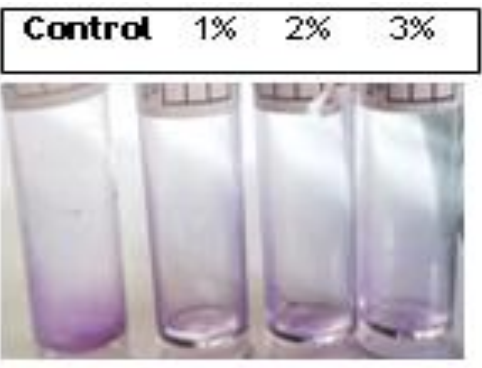

$6 \mathrm{~T}$

Fig. 10: Antibiofilm activity of Eucalyptus oil on oral Streptococci.

However; a few of which were stimulated (increase in adhesion or biofilm production ) at all concentrations as shown below in Fig. (11).This was also documented by (Lizana et al., 2014) in their study on antibiofilm activity of plant extracts. 


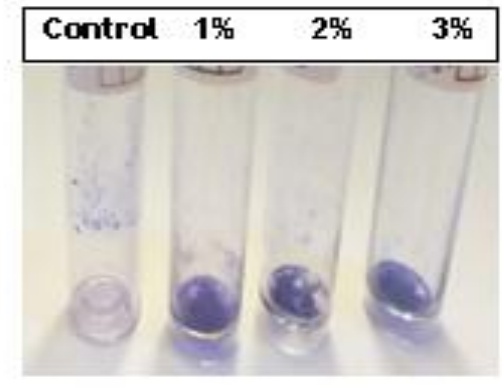

3u

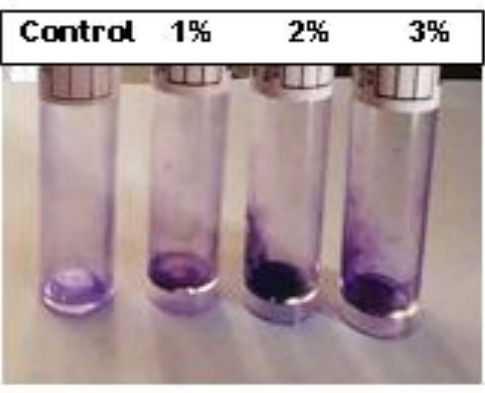

$7 \mathrm{~m}$

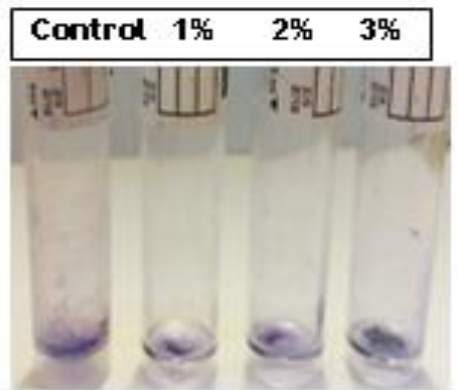

4 W

Fig. 11: Biofilm stimulating effect by Eucalyptus oil on some oral streptococci.

Microtiter plate assay:

This method was found to be more effective in detecting antibiofilm activity than the tube adherence method, as it was shown that the selected essential oils were able to decrease progression or inhibit biofilm formation by oral streptococci isolates.

Table (3) and (4) show the values of microtiter plate readings obtained using microtiter plate reader. Shaded values designate the values less than $\geq 0.12$ which indicate weak or no biofilm formation.

Table 3: Classification of bacterial adherence by microtiter plate (Mathur et al., 2006)

\begin{tabular}{cr}
\hline OD Value & BiofilmFormation \\
\hline$<0.120$ & Non-biofilm producer \\
$0.120-0.240$ & Moderate biofilm producer \\
$>0.240$ & Strong biofilm producer \\
\hline
\end{tabular}

Table 4: Optical Density readings of Microtiter plate antibiofilm assay

\begin{tabular}{c|c|c||c|c|c||c|c|c||c|c||c||c|}
\hline & \multicolumn{3}{|c}{ Cinnamon } & \multicolumn{3}{c|}{ Tea tree } & \multicolumn{3}{c|}{ Eucalyptus } & \multicolumn{3}{c|}{ Clove } \\
\hline \hline $3 T$ & $0.5 \% \%$ & $1 \%$ & $1.5 \% \%$ & $0.5 \% \%$ & $1 \%$ & $1.5 \% \%$ & $0.5 \% \%$ & $1 \%$ & $1.5 \% \%$ & $0.5 \% \%$ & $1 \%$ & $1.5 \% \%$ \\
\hline \hline $3 U$ & 0.045 & 0.053 & 0.164 & 0.092 & 0.206 & 0.194 & 0 & 0.12 & 0 & 0.065 & 0.17 & 0.427 \\
\hline \hline $5 T$ & 0.06 & 0.03 & 0.068 & 0.38 & 0.494 & 0.195 & 0.192 & 0.09 & 0.036 & 0.178 & 0.043 & 0.092 \\
\hline \hline $6 U$ & 0.079 & 0.037 & 0.084 & 0.068 & 0.064 & 0.071 & 0.098 & 0.111 & 0.125 & 0.043 & 0.388 & 0.192 \\
\hline \hline $6 T$ & 0.05 & 0.06 & 0.086 & 0.05 & 0.214 & 0.12 & 0.134 & 0.048 & 0.038 & 0.015 & 0.069 & 0.052 \\
\hline \hline $4 U$ & 0.555 & 0.043 & 0.054 & 0.488 & 0.112 & 0.237 & 0.062 & 0.065 & 0.035 & 0.019 & 0.06 & 0.068 \\
\hline \hline $4 m$ & 0.024 & 0.018 & 0.076 & 0.042 & 0.13 & 0.341 & 0.354 & 0.051 & 0.4 & 0.484 & 0.71 & 0.13 \\
\hline \hline $4 m x$ & 0.124 & 0.091 & 0.122 & 0.049 & 0.117 & 0.08 & 0.149 & 0.095 & 0.06 & 0.1 & 0.083 & 0.163 \\
\hline \hline $5 m$ & 0.089 & 0.09 & 0.118 & 0.077 & 0.04 & 0.07 & 0.244 & 0.055 & 0.053 & 0.478 & 0.217 & 0.061 \\
\hline \hline $7 m$ & 0.06 & 0.068 & 0.1 & 0.062 & 0.091 & 0.129 & 0.093 & 0.094 & 0.218 & 0.06 & 0.017 & 0.075 \\
\hline
\end{tabular}


Owing to their relative low cost and simplicity, staining methods are often used to quantify biofilm growth in microplate assays. However, the crystal violet staining method, originally described by (O'Toole and Kotter 1998) has become the "gold standard" for quantifying biofilms in a microtitre plate. It is an inexpensive technique that can be performed routinely with relative ease (O'Toole 2011) and can be applied for both gram positive and gram negative bacteria, for quantitative and qualitative biofilm formation on a variety of surfaces. The acceptance of this method cannot be overstated, as the original paper has been cited more than 2100 times since it was published in 1998 (Haney et al., 2018).

All selected essential oils demonstrated an antibiofilm activity in one concentration or another and as it is clear what affects one strain does not necessarily affect another. Best results were obtained by cinnamon being the most active in biofilm inhibition, followed by clove, eucalyptus and finally tea tree oil.

The demonstration of biofilm depends upon both the age of the culture and the fixation method used. The tube method was shown to be highly subjective, variable and produced different results from that of microtiter plate test. The importance of these technicalities was also concluded by (Deighton 1990). In summary, both methods categorized bacteria as adherent or non-adherent.

The results of this study deserve further attention; the spectrum and intensity of anti-biofilm activity demonstrated means that the selected essential oils should be investigated as an active antibiofilm ingredient in plastic products. It should also be further investigated as an active ingredient in products formulated to remove and/or prevent and treat, the production and accumulation of biofilm.

\section{REFERENCES}

Bauer, W.; Kirby, M.; Sherris, C.; Turk, M. (1966). Antibiotic susceptibility testing by a standardized single disk method. Am. J. Clin. Pathol., 45(4), 493-6.

Bruneton, J. (1999). "Pharmacognosy, Phytochemistry, Medicinal Plants". $2^{\text {nd }}$ ed. Paris: Lavoisier Publishing. pp. 405-467.

Christensen, D.; Simpson, A.; Younger, J.; Baddour, M.; Barrett, F.; Melton, M.; Beachey, H. (1985). Adherence of coagulase-negative staphylococci to plastic tissue culture plates: a quantitative model for the adherence of staphylococci to medical devices. J. Clin. Microbiol., 22(6), 996-1006.

Colagiorgi, A.; Ciccio, P.; Zanardi, E.; Ghidini, S.; Ianieri, A. (2016). A look inside the Listeria monocytogenes biofilms extracellular matrix. Microorganis.,4, 22.

Deighton, M.; Balkau, B. (1990). Adherence measured by microtiter assay as a virulence marker for Staphylococcus epidermidis infections. J. Clin. Microbiol., 28, 2442-2447.

Diego, F.; Theodora, C.; Geovany, G. ; Nairley, F.; Lucas, R.; Francisco, C. (2018). Antibacterial and antibiofilm activities of cinnamomum Sp. essential oil and cinnamaldehyde: antimicrobial activities. The Sci. Wrld. J., 2018,7405736.

Flemming, H.; Jost, W.; Ulrich, S.; Peter, S.; Scott, R.; Staffan, K. (2016). Biofilms: an emergent form of bacterial life. Nat. Rev. Microbiol., 14, 563-575.

Freeman, J.; Falkiner, R.; Keane, T. (1989). New method for detecting slime production by coagulase negative staphylococci. J. Clin. Pathol., 42(8),872-874.

Gondim, F.; Gilvan, R.; Igor, G.; Daniel, S.; Francisco, S. (2018). Beneficial effects of eucalyptol in the pathophysiological changes of the respiratory system: a proposal for alternative pharmacological therapy for individuals with COPD. Eur. J. Med. Plants., 25(1), 1-10.

Guevarra, Q. (2005). "A Guidebook to Plant Screening: Phytochemical and Biological, Manila". UST Publishing House, 156 p. 
Hammer, A.; Dry, L.; Johnson, M.; Michalak, M.; Carson, F.; Riley, V. (2003). Susceptibility of oral bacteria to Melaleuca alternifolia (tea tree) oil in vitro. Oral Microbiol. Immunol., 18(6), 389-92.

Haney, F.; Michael, J.; Trimble, M.; John, C.; Quentin, V.; Robert, H. (2018). Critical assessment of methods to quantify biofilm growth and evaluate antibiofilm activity of host defense peptides. Biomolecu., 8(2), 29.

Huang, F.; Xu, G.; Liu, X.; Zhang, H.; Hu, P. (2014). Chemical constituents, antibacterial activity and mechanism of action of the essential oil from Cinnamomum cassia bark against four food related bacteria. Microbiol., 83, 357-365.

Jitka, M.; Vladimir, B.; Pavel, K.; Josef, M.; Michal, S.; Lenka, C. (2017). Dynamics of mono- and dual-species biofilm formation and interactions between Staphylococcus aureus and Gramnegative bacteria. Microb. Biotechnol., 10(4), 819-832.

Kaplan, W.; Ma, X.; Paranjpe, A.; Jewett, A.; Lux, R.; Kinder-Haake, S. (2010). Fusobacterium nucleatum outer membrane proteins Fap2 and RadD induce cell death in human lymphocytes. Infect. Immun., 78, 4773-4778.

Katyayani, B.; Ayuba, B.; Raghavendra, S.; Mallikarajuna, P. (2017). Cinnamum genus: a review on its biological activities. Int. J. Pharm. Pharmaceut. Sci., 9.

Kolenbrander, E.; Palmer, J.; Jr Periasamy, S.; Jakubovics, S. (2010). Oral multispecies biofilm development and the key role of cell-cell distance. Nat. Rev. Microbiol., 8, 471-480.

Leite, L.; Mariana, M.; Mariana, D.; Natalia, I.; Andréa, G.; Yuri, C.; Wilton, P. ( 2017). Antibacterial Activity of Melaleuca alternifolia (tea tree essential oil) on Bacteria of the Dental Biofilm. Braz. Res. paed. Dent. Int. clin., 17(1).

Lizana, J.; Sergio, L.; Ana, M.; Ursula, S.; Diego, V.; Manuel, E. (2013). "Use of Plant Extracts to Block Bacterial Bioflm Formation". High School Students for Agricultural Sci. Res. Proceedings of the $3^{\text {rd }}$ Congress PIIISA, pp. 43-50.

Lopez, R.; Humberto, G.; Anabela, B.; Manuel, S. (2015). Antibacterial effects and mode of action of selected essential oils components against Escherichia coli and Staphylococcus aureus., eCAM 2015.

Lorene de França, L.; Mariana, M.; Mariana, M.; Natalia, P.; Andréa, G.; Yuri, C.; Wilton, P. (2017). Antibacterial activity of Melaleuca alternifolia (tea tree essential oil) on bacteria of the dental biofilm. Pesq. Bras. Odontoped.e Clin. Integ., 17(1).

Low, W.; Ken, K.; Stephen, B.; Mohd, A.; Claire, M. (2016). Essential oils and metal ions as alternative antimicrobial agents: a focus on tea tree oil and silver. Int. Wound J., 14(2), 369384.

Magee, P. (2007). Antiseptic drugs and disinfectants. Side Eff. Drugs Annu., 29, 241-243.

Mathur, S.; Khan, S.; Upadhyay, J.; Fatma, T.; Rattan, A.(2006). Detection of biofilm formation among the clinical isolates of staphylococci: An evaluation of three different screening methods. Indian J. Med. Microbiol., 24, 25-9.

Mota, V.; Ruth, T.; Vanessa de Brito, P. (2015). Antimicrobial activity of Eucalyptus globulus oil, xylitol and papain: a pilot study. Rev. Esc. enferm. USP., 49(2).

Nelson-Filho, P.; Borba, G.; Mesquita, S.; Silva, A.; Queiroz, M.; Silva, A. (2013). Dynamics of microbial colonization of the oral cavity in newborns. Braz. Dent. J., 24, 415-419.

O’Toole, A.; Kolter, R. (1998). Initiation of biofilm formation in Pseudomonas fluorescence WCS365 proceeds via multiple, convergent signaling pathways: A genetic analysis. Mol. Microbiol., 28,449-461.

O’Toole, A. (2011). Microtiter dish biofilm formation assay. J. Vis. Exp., 47, e2437. 
Pramodhini, S.; Niveditha, S.; Umadevi, S.; Kumar, S.; Stephen, S. (2012). Antibiotic resistance pattern of biofilm-forming uropathogens isolated from catheterized patients in Pondicherry, India. Australasian Medical., J. 5 (7), 344-348.

Reena, A.; Anandhalakshmi, S. (2017). Biofilm formation as a virulence factor of Acinetobacter baumannii: An emerging pathogen in critical care units. Rev. J. Cur. Res. in Sci. Med., 3(2), 74-78.

Ribeiro, M.; Joana, G.; Maria, F.; Manuel, S. (2018). Cytotoxicity and antimicrobial action of selected phytochemicals against planktonic and sessile Streptococcus mutans. Peer J., 6, e4872.

Sharma, N.; Sonu, B.; Abhinashi, S.; Navneet, B. (2018). Oral microbiome and health (review). AIMS Microbial., 4(1), 42-66).

Roberts, P.; Kreth, J. (2014). The impact of horizontal gene transfer on the adaptive ability of the human oral microbiome. Front. Cell. Infect. Mi., 4, 124.

Rodríguez, O.; Sánchez, R.; Verde, M.; Núñez, M.; Ríos, R.; Chávez, A. (2014).Obtaining the essential oil of Syzygium aromaticum, identification of eugenol and its effect on Streptococcus mutans. J. Oral Res., 3(4), 218.

Rohraff, D.; Roderick, M. (2016). The antibiotic activity of tea tree, eucalyptus, and cinnamon bark oils. The FASEB J. Abstract Number: lb124.

Singh, R.; Vadhana, P.; Bhardwaj, M.; Vinodh, R.; Sinha, K. (2016). Comparative antimicrobial activity of tea tree oil (Melaleuca Oil) and common topical antimicrobials against bacteria associated with wound and topical infections. Pharm. Anal. Acta., 7, 513.

Sreevidhya, M.; Geetha V. (2014). Antibacterial activity of the three essential oils on Streptococcus mutans- an in-vitro study. Int. J. Drug Develop. Res.

Swamy, K.; Mohd, A.; Uma, S. (2015). Antimicrobial properties of plant essential oils against human pathogens and their mode of action: an updated review. eCAM. Article ID 506413, 9 pages.

Thosar, N.; Silpi, B.; Rakesh, B.; Monali, R. (2013). Antimicrobial efficacy of five essential oils against oral pathogens: An in vitro study. Eur. J. Dent., 7 (5),71-77.

Wang, Y.; Zhang, Y.; Shi, Q.; Pan, H.; Lu, H.; Cao, P. (2018). Antibacterial effects of cinnamon (Cinnamomum zeylanicum) bark essential oil on Porphyromonas gingivalis. Microb. Pathog., 116,26-32.

Wazir bin Jumali, A.; Mieke, S.; Warta, P. (2013). Antibacterial effect of clove (Eugenia aromaticum) oil extracted from clove cigarettes towards Streptococcus mutans. J. Dentist., 25(1), 21-25.

Zhang, Y.; Dongyang, X.; Lei, S.; Rujian, C.; Chunling L. (2018). Association between agr type, virulence factors, biofilm formation and antibiotic resistance of Staphylococcus aureus isolates from pork production. Front Microbiol., 9, 1876. 